\title{
Content and Bioaccumulation of Nine Mineral Elements in Ten Mushroom Species of the Genus Boletus
}

\author{
Xue-Mei Wang, ${ }^{1}$ Ji Zhang, ${ }^{2}$ Tao Li, ${ }^{3}$ Yuan-Zhong Wang, ${ }^{2}$ and Hong-Gao Liu ${ }^{1}$ \\ ${ }^{1}$ College of Agronomy and Biotechnology, Yunnan Agricultural University, Kunming 650201, China \\ ${ }^{2}$ Institute of Medicinal Plants, Yunnan Academy of Agricultural Sciences, Kunming 650200, China \\ ${ }^{3}$ College of Resources and Environment, Yuxi Normal University, Yuxi 653100, China \\ Correspondence should be addressed to Yuan-Zhong Wang; boletus@126.com and Hong-Gao Liu; honggaoliu@126.com
}

Received 11 May 2015; Revised 26 May 2015; Accepted 27 May 2015

Academic Editor: Filomena Conforti

Copyright (C) 2015 Xue-Mei Wang et al. This is an open access article distributed under the Creative Commons Attribution License, which permits unrestricted use, distribution, and reproduction in any medium, provided the original work is properly cited.

\begin{abstract}
Concentrations and bioconcentration potential of nine elements ( $\mathrm{Ca}, \mathrm{Cu}, \mathrm{Fe}, \mathrm{K}, \mathrm{Mg}, \mathrm{Mn}, \mathrm{Na}, \mathrm{P}$, and $\mathrm{Zn}$ ) in ten species of wild edible Boletus and the corresponding underlying soils were analyzed. The analyses were performed using inductively coupled plasma atomic emission spectrophotometer. Boletus showed relative abundant contents of $\mathrm{P}, \mathrm{K}, \mathrm{Fe}, \mathrm{Mg}, \mathrm{Ca}$, and $\mathrm{Na}$ and less of $\mathrm{Zn}, \mathrm{Cu}$, and $\mathrm{Mn}$. Caps compared to stalks were enriched in $\mathrm{P}, \mathrm{K}, \mathrm{Cu}, \mathrm{Mg}$, and $\mathrm{Zn}$, while stalks were enriched in $\mathrm{Mn}$. The elements such as $\mathrm{P}$ and $\mathrm{K}$ were accumulated $(\mathrm{BCF}>1)$, while $\mathrm{Ca}, \mathrm{Fe}, \mathrm{Mg}, \mathrm{Mn}$, and $\mathrm{Na}$ were excluded $(\mathrm{BCF}<1)$ in the fruiting bodies. The correlation analysis indicated high correlations between $\mathrm{Cu}, \mathrm{Mn}, \mathrm{Ca}$, and $\mathrm{Fe}$ in the mushrooms as compared to the corresponding soils. Significant correlations were also obtained between $\mathrm{Cu}-\mathrm{P}(r=0.775), \mathrm{Fe}-\mathrm{P}(r=0.728)$, and $\mathrm{Zn}-\mathrm{P}(r=0.76)$ for caps and $\mathrm{Cu}-\mathrm{Mg}(r=0.721), \mathrm{Fe}-\mathrm{Mg}(r=0.719), \mathrm{Zn}-\mathrm{Mg}(r=0.824)$, and $\mathrm{Zn}-\mathrm{P}(r=0.818)$ for stalks. The results of this study imply that ability of fungi to accumulate elements from substrate could be influenced by mushroom species and underlying soil substrates.
\end{abstract}

\section{Introduction}

Mushrooms are traditionally recognized as a valued source of nutrients and a popular delicacy in many countries for their rich contents in proteins, essential minerals, and low energy levels [1]. Edible wild-grown mushrooms consumption has been preferred to cultivated species for their indisputable flavor, texture, and medicinal properties [2,3]. Proteins of wild edible mushrooms are usually high, commonly ranging between $10 \%$ and $60 \%$, which were calculated using the conversion factor of 4.38 [1]. Mushroom gathering has been a very popular leisure and commercial activity in many European and Asian countries [4]

Macromycetes in nature play a major role in biogeochemical transformation of macro- and microelements essential to humans [5]. Wild mushrooms can absorb large amounts of water and minerals within a relatively short period due to large area of mycelium overgrowing the surface layer of soil [6]. Abundance of minerals such as $\mathrm{P}, \mathrm{K}, \mathrm{Ca}, \mathrm{Mg}, \mathrm{Na}, \mathrm{Fe}, \mathrm{Mn}$, $\mathrm{Zn}$, and $\mathrm{Cu}$ desired in human nutrition has been reported in edible wild-grown mushrooms; meanwhile, undesired high levels of toxic elements including $\mathrm{As}, \mathrm{Hg}, \mathrm{Cd}$, and $\mathrm{Pb}$ were also found in previous studies [5]. Bioconcentration factor (BCF) is the ratio of the element content in fruiting body (cap or stalk) to the content in underlying substrate, which can express the ability of fungi to accumulate elements from substrate [7]. If BCF exceeds unity (BCF $>1)$ it indicates the accumulation of elements in fungus, and if $\mathrm{BCF}$ is below unity $(\mathrm{BCF}<1)$ it excludes bioaccumulation [8]. Bioaccumulation capacity of mushroom is usually affected by fungal lifestyle, age of fruiting body, specific species and element, and environment such as $\mathrm{pH}$, organic matter, and pollution [5].

Rich resources of wild edible fungi are distributed in Yunnan province (southwest of China) due to the mild and rainy climate. Laterite, lateritic red loam, red soil, yellow soil, and brown soil are the main agrotypes in Yunnan [9]. Contents of elements such as $\mathrm{Cu}, \mathrm{Fe}, \mathrm{Pb}, \mathrm{Cd}, \mathrm{Co}, \mathrm{Se}, \mathrm{Ni}, \mathrm{V}, \mathrm{Tl}, \mathrm{Sc}$, and $\mathrm{Ti}$ in soil are rather high, which would be the primary sources of elements to fungi [10]. More than 880 species of wild-grown mushrooms were identified as edible in Yunnan province, which account for $80 \%$ in China and $40 \%$ in the world [11]. Export volume of wild edible mushrooms in Yunnan was 
TABLE 1: Families, habitat, and number of analyzed fruiting bodies.

\begin{tabular}{llc}
\hline Species & Habitat & Number \\
\hline Boletus speciosus Frost & On mixed woods ground & 10 \\
Boletus griseus Frost & On needles, oak, and chestnut forest ground & 10 \\
Boletus luridus Schaeff. & On broadleaf or mixed woods ground & 8 \\
Boletus umbriniporus Hongo & On forest ground & 8 \\
Boletus tomentipes Earle & On needles and broadleaf forest ground & 7 \\
Boletus edulis Bull. & On mixed coniferous and broadleaf forest ground & 10 \\
Boletus pallidus Frost & On shaw ground & 9 \\
Boletus brunneissimus W.F. Chiu & On mixed pine tree and katue forest ground & 9 \\
Boletus rubellus Krombh. & On broadleaf or mixed woods ground & 7 \\
Boletus aereus Bull. & On oak forest ground & 7 \\
\hline
\end{tabular}

105000 and 135000 tons, and the exports were 1.21 and 1.43 million dollars in 2010 and 2011, respectively. Species of the genus Boletus and Tricholoma matsutake are the main export varieties, which account for $90 \%$ of the total export in Yunnan [12].

Species of the genus Boletus are a popular food throughout the world because of their particular aroma, sensory qualities, texture, and biologically active compounds. Flavor of the favorite dried species such as Boletus edulis, Boletus aereus, and Boletus badius includes odor and marvelous taste of nuttiness, earthiness, and meatiness [13]. 199 species of Boletales were identified as edible in China, among which 144 species were distributed in Yunnan province [14]. Boletus is abundant in proteins, carbohydrates, vitamins, and essential elements required in the human body. Furthermore, its history of traditional use in oriental therapies and modern clinical practice has been reported such as use as for its anti-inflammatory, antimicrobial, antioxidant, antiviral, antitumor, and immunomodulatory activities and its use for reduction of blood glucose levels [15]. However, species such as Boletus edulis, Boletus badius, Boletus griseus, and Boletus pinophilus contained high contents of toxic $\mathrm{Cd}, \mathrm{Hg}$, As, and $\mathrm{Pb}[5,16,17]$. Also undesired $\mathrm{Ag}$ and $\mathrm{Sb}$ can be elevated in some wildgrown mushrooms $[18,19]$.

There was little information available about bioaccumulation ability of elements in Boletus family in China. Since these mushrooms have been traditionally used for consumption by local people and trading, the aim of this study was to determine the contents of nine elements ( $\mathrm{Ca}, \mathrm{Cu}, \mathrm{Fe}, \mathrm{K}, \mathrm{Mg}, \mathrm{Mn}$, $\mathrm{Na}, \mathrm{P}$, and $\mathrm{Zn}$ ) in ten species of edible Boletus and the underlying soil to investigate the relationship between fruiting body and habitat.

\section{Materials and Methods}

2.1. Sampling. Mature fruiting bodies of ten edible species of the genus Boletus were collected from Yunnan province (southwest of China) during summer and autumn in 2012. The species, habitat, and number of fruiting bodies are given in Table 1 . The underlying surface layers $(0$ to $10 \mathrm{~cm}$ ) were collected after removing the superficial layer of litter and organic detritus.
Fresh fruiting bodies of Boletus were cleaned from plant and substrate debris with a plastic knife and divided into two parts (caps and stalk) and then washed with deionized water. Each sample was dried in an electrically heated oven at $65^{\circ} \mathrm{C}$ to constant weight. Dried samples were pulverized with laboratory mill and kept in sealed polyethylene bags in dry conditions. Substrate samples were air-dried at room temperature for several weeks and passed through a 100-mesh sieve.

2.2. Digestion Process. Dried mushroom samples were weighed as $0.3 \mathrm{~g}$ accurately and placed into the polytetrafluoroethylene (PTFE) pressure vessels. $4 \mathrm{~mL} \mathrm{HNO}_{3}$ (65\%) and $2 \mathrm{~mL} \mathrm{H}_{2} \mathrm{O}_{2}(30 \%)$ were added to the vessel and digested under pressure in an automatic microwave digestion system, Ethos One (Milestone, Italy). The extract was further diluted to $25 \mathrm{~mL}$ using deionized water.

Soil samples $(0.1 \mathrm{~g})$ were placed into the polytetrafluoroethylene beaker and digested and mixed with $6 \mathrm{~mL} \mathrm{HNO}_{3}$ $(65 \%)$ and $1 \mathrm{~mL} \mathrm{HClO}_{4}(72 \%)$ on an electric hot plate at $170^{\circ} \mathrm{C}$, removing and cooling the samples when they turned into paste. Then the paste was dissolved in $10 \mathrm{~mL} \mathrm{HF} \mathrm{(40 \% )} \mathrm{and}$ $0.5 \mathrm{~mL} \mathrm{HClO}_{4}(72 \%)$ and heated again at $210 \sim 220^{\circ} \mathrm{C}$ until the acid evaporated completely. Further, $10 \mathrm{~mL} \mathrm{HCl} \mathrm{(38 \% )} \mathrm{was}$ added and heated until dissolved and diluted with distilled water up to $25 \mathrm{~mL}$.

2.3. Analytical Determination. All elements ( $\mathrm{Ca}, \mathrm{Cu}, \mathrm{Fe}, \mathrm{K}$, $\mathrm{Mg}, \mathrm{Mn}, \mathrm{Na}, \mathrm{P}$, and $\mathrm{Zn}$ ) contents in dry weight ( $\mathrm{dw}$ ) of mushrooms and soils samples were determined using inductively coupled plasma atomic emission spectrophotometer (ICPE9000, Shimadzu, Japan). The repeatability for all determined elements was less than 5\%. Limits of quantitation (LOQ) for $\mathrm{Ca}, \mathrm{Cu}, \mathrm{Fe}, \mathrm{K}, \mathrm{Mg}, \mathrm{Mn}, \mathrm{Na}, \mathrm{P}$, and $\mathrm{Zn}$ were $0.04,0.17,0.18,2.16$, $0.04,0.01,1.53,0.44$, and $0.05 \mathrm{mg} / \mathrm{kg} \mathrm{dw}$, respectively. The efficiency of the process was validated with $94-107 \%$ recovery success using certified reference materials, namely, tea leaves (GBW07605) and soils (GBW07406), both produced by the Institute of Geophysical and Geochemical Exploration in Beijing, China. 
TABLE 2: Elements content in the caps and stipes of Boletus and underlying soil (mg/kg dw, mean, SD).

\begin{tabular}{|c|c|c|c|c|c|c|c|c|c|c|}
\hline Species & & $\mathrm{Ca}$ & $\mathrm{Cu}$ & $\mathrm{Fe}$ & $\mathrm{K}$ & $\mathrm{Mg}$ & $\mathrm{Mn}$ & $\mathrm{Na}$ & $\mathrm{P}$ & $\mathrm{Zn}$ \\
\hline \multirow{3}{*}{ Boletus speciosus } & Cap & $172 \pm 36$ & $66 \pm 12$ & $1021 \pm 216$ & $9017 \pm 453$ & $909 \pm 158$ & $21 \pm 6$ & $130 \pm 76$ & $5612 \pm 587$ & $148 \pm 25$ \\
\hline & Stipe & $141 \pm 91$ & $22 \pm 5$ & $959 \pm 232$ & $6105 \pm 829$ & $504 \pm 307$ & $30 \pm 2$ & $118 \pm 13$ & $2218 \pm 573$ & $56 \pm 26$ \\
\hline & Soil & $449 \pm 234$ & $35 \pm 21$ & $20081 \pm 3426$ & $3169 \pm 432$ & $1134 \pm 673$ & $140 \pm 32$ & $876 \pm 27$ & $656 \pm 32$ & $63 \pm 2$ \\
\hline \multirow{3}{*}{ Boletus griseus } & Cap & $538 \pm 56$ & $40 \pm 13$ & $1166 \pm 133$ & $17310 \pm 667$ & $577 \pm 54$ & $48 \pm 22$ & $324 \pm 26$ & $7126 \pm 334$ & $205 \pm 55$ \\
\hline & Stipe & $512 \pm 32$ & $24 \pm 6$ & $1194 \pm 244$ & $15308 \pm 565$ & $407 \pm 75$ & $63 \pm 22$ & $226 \pm 13$ & $4789 \pm 454$ & $125 \pm 52$ \\
\hline & Soil & $1076 \pm 32$ & $39 \pm 13$ & $26989 \pm 2411$ & $5373 \pm 3458$ & $1169 \pm 113$ & $459 \pm 89$ & $1020 \pm 675$ & $1686 \pm 242$ & $113 \pm 7$ \\
\hline \multirow{3}{*}{ Boletus luridus } & Cap & $475 \pm 29$ & $65 \pm 13$ & $1600 \pm 345$ & $11206 \pm 677$ & $556 \pm 81$ & $67 \pm 23$ & $105 \pm 12$ & $6832 \pm 565$ & $131 \pm 18$ \\
\hline & Stipe & $395 \pm 165$ & $20 \pm 12$ & $1117 \pm 212$ & $7594 \pm 434$ & $340 \pm 223$ & $85 \pm 21$ & $90 \pm 27$ & $2742 \pm 345$ & $51 \pm 23$ \\
\hline & Soil & $2438 \pm 341$ & $54 \pm 23$ & $28210 \pm 788$ & $6665 \pm 178$ & $2694 \pm 252$ & $773 \pm 95$ & $2292 \pm 321$ & $1293 \pm 132$ & $87 \pm 54$ \\
\hline \multirow{3}{*}{ Boletus umbriniporus } & Cap & $166 \pm 33$ & $43 \pm 11$ & $747 \pm 256$ & $10740 \pm 234$ & $431 \pm 56$ & $21 \pm 4$ & $421 \pm 67$ & $5325 \pm 453$ & $90 \pm 23$ \\
\hline & Stipe & $95 \pm 12$ & $34 \pm 13$ & $357 \pm 32$ & $8360 \pm 568$ & $279 \pm 32$ & $26 \pm 5$ & $451 \pm 134$ & $2176 \pm 234$ & $33 \pm 6$ \\
\hline & Soil & $758 \pm 54$ & $26 \pm 12$ & $19966 \pm 4663$ & $5154 \pm 126$ & $990 \pm 645$ & $315 \pm 13$ & $2071 \pm 234$ & $1778 \pm 543$ & $110 \pm 78$ \\
\hline \multirow{3}{*}{ Boletus tomentipes } & & $99 \pm 45$ & $48 \pm 6$ & $376 \pm 32$ & $11488 \pm 345$ & & $17 \pm 2$ & & $5155 \pm 324$ & $115 \pm 45$ \\
\hline & Stipe & & $28 \pm 5$ & $751 \pm 65$ & $10775 \pm 454$ & & & & $3089 \pm 235$ & $90 \pm 6$ \\
\hline & Soil & $1081 \pm 38$ & & $38286 \pm 479$ & $5761 \pm 46$ & & & & $850 \pm 46$ & $108 \pm 23$ \\
\hline \multirow{3}{*}{ Boletus edulis } & & & & & & & & & & $88 \pm 4$ \\
\hline & Stipe & & & $4200 \pm 678$ & & & & & $2429 \pm 545$ & $41 \pm 33$ \\
\hline & Soil & $1624 \pm 45$ & $152 \pm 20$ & $52613 \pm 656$ & $8533 \pm 234$ & $3665 \pm 867$ & $945 \pm 77$ & $1972 \pm 45$ & $1495 \pm 22$ & $118 \pm 67$ \\
\hline \multirow{3}{*}{ Boletus pallidus } & Cap & $342 \pm 234$ & $78 \pm 6$ & $1475 \pm 56$ & $18968 \pm 676$ & $1239 \pm 82$ & $36 \pm 2$ & $601 \pm 4$ & $10611 \pm 234$ & $45 \pm 76$ \\
\hline & Stipe & $378 \pm 56$ & $39 \pm 4$ & $1823 \pm 341$ & $15325 \pm 459$ & $935 \pm 240$ & $39 \pm 22$ & $500 \pm 345$ & $5621 \pm 248$ & $37 \pm 9$ \\
\hline & Soil & $2624 \pm 787$ & $261 \pm 55$ & $83294 \pm 676$ & $3617 \pm 89$ & $1745 \pm 456$ & $1092 \pm 88$ & $1288 \pm 67$ & $1330 \pm 234$ & $396 \pm 78$ \\
\hline \multirow{3}{*}{ Boletus brunneissimus } & Cap & $669 \pm 34$ & $33 \pm 23$ & $741 \pm 78$ & $11757 \pm 346$ & $759 \pm 21$ & $29 \pm 8$ & $472 \pm 44$ & $4942 \pm 986$ & $167 \pm 50$ \\
\hline & Stipe & $154 \pm 78$ & $16 \pm 4$ & $702 \pm 23$ & $10320 \pm 654$ & $513 \pm 78$ & $38 \pm 2$ & $216 \pm 56$ & $2949 \pm 873$ & $88 \pm 57$ \\
\hline & Soil & $1879 \pm 245$ & $50 \pm 14$ & $32165 \pm 343$ & $6765 \pm 652$ & $1307 \pm 45$ & $744 \pm 22$ & $891 \pm 454$ & $2007 \pm 13$ & $145 \pm 29$ \\
\hline \multirow{3}{*}{ Boletus rubellus } & Cap & $285 \pm 67$ & $56 \pm 34$ & $1376 \pm 46$ & $11606 \pm 428$ & $773 \pm 65$ & $41 \pm 16$ & $203 \pm 46$ & $5888 \pm 106$ & $223 \pm 54$ \\
\hline & Stipe & $632 \pm 35$ & $35 \pm 21$ & $3488 \pm 785$ & $10732 \pm 345$ & $631 \pm 76$ & $71 \pm 13$ & $340 \pm 78$ & $4853 \pm 906$ & $131 \pm 86$ \\
\hline & Soil & $3289 \pm 442$ & $159 \pm 45$ & $57870 \pm 466$ & $5675 \pm 545$ & $1802 \pm 42$ & $682 \pm 24$ & $825 \pm 74$ & $2176 \pm 346$ & $251 \pm 57$ \\
\hline \multirow{3}{*}{ Boletus aereus } & Cap & $140 \pm 21$ & $61 \pm 41$ & $654 \pm 45$ & $11365 \pm 343$ & $758 \pm 67$ & $26 \pm 3$ & $546 \pm 50$ & $5467 \pm 535$ & $165 \pm 24$ \\
\hline & Stipe & $139 \pm 6$ & $37 \pm 5$ & $2323 \pm 210$ & $7905 \pm 676$ & $556 \pm 35$ & $77 \pm 4$ & $291 \pm 65$ & $2497 \pm 342$ & $75 \pm 6$ \\
\hline & Soil & $687 \pm 43$ & $60 \pm 3$ & $34440 \pm 652$ & $5675 \pm 874$ & $1535 \pm 257$ & $378 \pm 35$ & $2393 \pm 256$ & $695 \pm 57$ & $77 \pm 20$ \\
\hline
\end{tabular}

\section{Results and Discussion}

3.1. Element Concentrations. The element contents in fruiting bodies of Boletus (cap and stalk) and underlying soil samples are presented in Table 2 . As previously reported, fruiting bodies of Boletus can be considered as rich in $\mathrm{P}, \mathrm{K}, \mathrm{Na}, \mathrm{Ca}$, and $\mathrm{Mg}$ and also abundant in trace elements such as $\mathrm{Cu}, \mathrm{Zn}$, and $\mathrm{Mn}$. Among the minerals determined in this study, $\mathrm{K}, \mathrm{P}, \mathrm{Fe}, \mathrm{Mg}$, and $\mathrm{Ca}$ exhibited higher concentrations than $\mathrm{Na}, \mathrm{Zn}, \mathrm{Cu}$, and $\mathrm{Mn}$, which is in accordance with the literature [7]. While Boletus collected from Yunnan contained lower levels of $\mathrm{K}, \mathrm{Na}$, $\mathrm{Ca}, \mathrm{Mg}, \mathrm{Fe}$, and $\mathrm{Mn}$ than other reports [20], significant differences were obtained not only among various Boletus species but also within different part of fruiting body (Table 2). Similarly to previous studies, the ranges of concentrations spread over one to two orders of magnitude often occurred [21,22].

Among the mushroom species analyzed, the greatest contents of $\mathrm{Cu}, \mathrm{K}, \mathrm{Mg}, \mathrm{Na}$, and $\mathrm{P}$ were quantified in the caps and stalks of Boletus pallidus, and $\mathrm{Mn}$ and $\mathrm{Zn}$ were found in Boletus luridus and Boletus rubellus. Highest $\mathrm{Ca}$ and $\mathrm{Fe}$ contents were found in the caps of Boletus brunneissimus and stipes of Boletus edulis, namely, 669 and $4200 \mathrm{mg} / \mathrm{kg} \mathrm{dw}$, respectively. In the study by Zhou and Yin (2008) [23], Boletus edulis showed higher contents of $\mathrm{K}, \mathrm{Na}, \mathrm{Ca}, \mathrm{Mg}$, and $\mathrm{Fe}$ than Boletus speciosus and Boletus aereus. In our early study, values of 13.6, 121, 248, and $20.3 \mathrm{mg} / \mathrm{kg} \mathrm{dw}$ for $\mathrm{Cu}, \mathrm{Fe}, \mathrm{Mg}$, and $\mathrm{Zn}$ were determined in Boletus tomentipes, respectively, which are lower than the present results [24]. Similarly, contents of $\mathrm{K}, \mathrm{Ca}, \mathrm{Fe}, \mathrm{Mg}$, and $\mathrm{Zn}$ for Boletus speciosus and Boletus griseus collected from Yunnan province in 2009 were lower than the data in Table 2 [25].

$\mathrm{K}$ contents in caps and stalks of Boletus edulis (cap: $29000 \mathrm{mg} / \mathrm{kg}$, stalk: $20000 \mathrm{mg} / \mathrm{kg} \mathrm{dw}$ ) and Boletus subtomentosus (cap: $46000 \mathrm{mg} / \mathrm{kg}$, stalk: $43000 \mathrm{mg} / \mathrm{kg} \mathrm{dw}$ ) from Poland were much higher than the values in our study (cap: 9017$18968 \mathrm{mg} / \mathrm{kg}$, stalk: $4865-15325 \mathrm{mg} / \mathrm{kg} \mathrm{dw}$ ) [8, 26]. P contents were found at the ranges of $4942-10611 \mathrm{mg} / \mathrm{kg} \mathrm{dw}$ and $2176-$ $5621 \mathrm{mg} / \mathrm{kg} \mathrm{dw}$ for caps and stalks of Boletus, respectively. Higher values were found to be $8700-16000 \mathrm{mg} / \mathrm{kg}$ dw in caps and $4100-7500 \mathrm{mg} / \mathrm{kg} \mathrm{dw}$ in stalks of Macrolepiota procera, 
TABLE 3: Daily metal intakes by a normal, $60 \mathrm{~kg}$ consumer in $\mathrm{mg} / \mathrm{serving}$.

\begin{tabular}{|c|c|c|c|c|c|c|c|c|c|c|}
\hline Species & & $\mathrm{Ca}$ & $\mathrm{Cu}$ & $\mathrm{Fe}$ & $\mathrm{K}$ & $\mathrm{Mg}$ & $\mathrm{Mn}$ & $\mathrm{Na}$ & $\mathrm{P}$ & $\mathrm{Zn}$ \\
\hline \multirow{2}{*}{ Boletus speciosus } & Cap & $5.16 \pm 1.08$ & $1.98 \pm 0.36$ & $30.6 \pm 6.48$ & $271 \pm 13.6$ & $27.3 \pm 4.74$ & $0.63 \pm 0.18$ & $3.9 \pm 2.28$ & $168.4 \pm 17.6$ & $4.44 \pm 0.75$ \\
\hline & Stipe & $4.23 \pm 2.73$ & $0.66 \pm 0.15$ & $28.8 \pm 6.96$ & $183 \pm 24.9$ & $15.1 \pm 9.21$ & $0.9 \pm 0.06$ & $3.54 \pm 0.39$ & $66.5 \pm 17.3$ & $1.68 \pm 0.78$ \\
\hline \multirow{2}{*}{ Boletus griseus } & Cap & $16.1 \pm 1.68$ & $1.2 \pm 0.39$ & $35.0 \pm 3.99$ & $519 \pm 20.0$ & $17.3 \pm 1.62$ & $1.44 \pm 0.66$ & $9.72 \pm 0.78$ & $214 \pm 10.0$ & $6.15 \pm 1.65$ \\
\hline & Stipe & $15.4 \pm 0.96$ & $0.72 \pm 0.18$ & $35.8 \pm 7.32$ & $459 \pm 17.0$ & $12.2 \pm 2.25$ & $1.89 \pm 0.66$ & $6.78 \pm 0.39$ & $144 \pm 13.6$ & $3.75 \pm 1.56$ \\
\hline \multirow{2}{*}{ Boletus luridus } & Cap & $14.3 \pm 0.87$ & $1.95 \pm 0.39$ & $48 \pm 10.4$ & $336 \pm 20.3$ & $16.7 \pm 21.43$ & $2.01 \pm 0.69$ & $3.15 \pm 0.36$ & $205 \pm 17.0$ & $3.93 \pm 0.54$ \\
\hline & Stipe & $11.9 \pm 4.95$ & $0.6 \pm 0.36$ & $33.5 \pm 6.36$ & $228 \pm 13.0$ & $10.2 \pm 6.69$ & $2.55 \pm 0.63$ & $2.7 \pm 0.81$ & $82.3 \pm 10.4$ & $1.53 \pm 0.69$ \\
\hline \multirow{2}{*}{ Boletus umbriniporus } & Cap & $4.98 \pm 0.99$ & $1.29 \pm 0.33$ & $22.4 \pm 7.68$ & $322 \pm 7.02$ & $12.9 \pm 1.68$ & $0.63 \pm 0.12$ & $12.6 \pm 2.01$ & $160 \pm 13.4$ & $2.7 \pm 0.69$ \\
\hline & Stipe & $2.85 \pm 0.36$ & $1.02 \pm 0.39$ & $10.7 \pm 0.96$ & $251 \pm 17.0$ & $8.37 \pm 0.96$ & $0.78 \pm 0.15$ & $13.5 \pm 4.02$ & $65.3 \pm 7.02$ & $0.99 \pm 0.18$ \\
\hline \multirow{2}{*}{ Boletus tomentipes } & Cap & $2.97 \pm 1.35$ & $1.44 \pm 0.18$ & & $345 \pm 10.4$ & $11.6 \pm 7.02$ & & & $155 \pm 9.72$ & $3.45 \pm 1.35$ \\
\hline & Stipe & $3.39 \pm 1.02$ & $0.84 \pm 0.15$ & $22.5 \pm 1.95$ & $323 \pm 13.6$ & $9.42 \pm 0.96$ & $1.14 \pm 0.09$ & $3.21 \pm 2.28$ & $92.7 \pm 7.05$ & $2.7 \pm 0.18$ \\
\hline \multirow{2}{*}{ Boletus edulis } & Cap & $9.6 \pm 0.78$ & $1.53 \pm 1.02$ & $27.9 \pm 2.46$ & $282 \pm 17.0$ & $12.9 \pm 1.62$ & $0.78 \pm 0.33$ & $5.73 \pm 1.59$ & $198 \pm 10.3$ & $2.64 \pm 0.12$ \\
\hline & Stipe & $9.5 \pm 0.99$ & $0.96 \pm 0.12$ & $126 \pm 20.3$ & $146 \pm 7.35$ & $8.91 \pm 1.95$ & $2.1 \pm 0.39$ & $3.66 \pm 0.69$ & $72.9 \pm 16.4$ & $1.23 \pm 0.99$ \\
\hline \multirow{2}{*}{ Boletus pallidus } & Cap & $10.3 \pm 7.02$ & $2.34 \pm 0.18$ & $44.3 \pm 1.68$ & $569 \pm 20.3$ & $37.2 \pm 2.46$ & $1.08 \pm 0.06$ & $18.0 \pm 0.12$ & $318 \pm 7.02$ & $1.35 \pm 2.28$ \\
\hline & Stipe & $11.3 \pm 1.68$ & $1.17 \pm 0.12$ & $54.7 \pm 10.2$ & $460 \pm 13.8$ & $28.1 \pm 7.2$ & $1.17 \pm 0.66$ & $15 \pm 10.4$ & $168.6 \pm 7.44$ & $1.11 \pm 0.27$ \\
\hline \multirow{2}{*}{ Boletus brunneissimus } & Cap & $20.1 \pm 1.02$ & $0.99 \pm 0.69$ & $22.2 \pm 2.34$ & $353 \pm 10.4$ & $22.8 \pm 0.63$ & $0.87 \pm 0.24$ & $14.2 \pm 1.32$ & $148 \pm 29.6$ & $5.01 \pm 1.5$ \\
\hline & Stipe & $4.62 \pm 2.34$ & $0.48 \pm 0.12$ & $21.1 \pm 0.69$ & $310 \pm 19.6$ & $15.4 \pm 2.34$ & $1.14 \pm 0.06$ & $6.48 \pm 1.68$ & $88.5 \pm 26.2$ & $2.64 \pm 1.71$ \\
\hline \multirow{2}{*}{ Boletus rubellus } & Cap & $8.55 \pm 2.01$ & $1.68 \pm 1.02$ & $41.3 \pm 1.38$ & $348 \pm 12.8$ & $23.2 \pm 1.95$ & $1.23 \pm 0.48$ & $6.09 \pm 1.38$ & $177 \pm 3.18$ & $6.69 \pm 1.62$ \\
\hline & Stipe & $19.0 \pm 1.05$ & $1.05 \pm 0.63$ & $105 \pm 23.6$ & $322 \pm 10.4$ & $18.9 \pm 2.28$ & $2.13 \pm 0.39$ & $10.2 \pm 2.34$ & $146 \pm 27.2$ & $3.93 \pm 2.58$ \\
\hline \multirow{2}{*}{ Boletus aereus } & Cap & $4.2 \pm 0.63$ & $1.83 \pm 1.23$ & $19.6 \pm 1.35$ & $341 \pm 10.3$ & $22.7 \pm 2.01$ & $0.78 \pm 0.09$ & $16.4 \pm 1.5$ & $164 \pm 16.1$ & $4.95 \pm 0.72$ \\
\hline & Stipe & $4.17 \pm 0.18$ & $1.11 \pm 0.15$ & $69.7 \pm 6.3$ & $237 \pm 20.3$ & $16.7 \pm 1.05$ & $2.31 \pm 0.12$ & $8.73 \pm 1.95$ & $74.9 \pm 10.3$ & $2.25 \pm 0.18$ \\
\hline
\end{tabular}

and lower values of $640-4490 \mathrm{mg} / \mathrm{kg} \mathrm{dw}$ were for the fruiting body of thirty macrofungi species from Turkey $[27,28]$.

The range of Fe contents in this study was 376-1600 in caps and $357-4200 \mathrm{mg} / \mathrm{kg} \mathrm{dw}$ in stalks, which are much higher than the values previously reported $[8,29]$. Similar values were found to be $150-1741 \mathrm{mg} / \mathrm{kg} \mathrm{dw}$, and a particularly higher value was $11460 \mathrm{mg} / \mathrm{kg} \mathrm{dw}$ for Lepista nuda [30, 31]. Reported Ca contents in Boletus edulis, Boletus speciosus, and Boletus tomentipes were 913.9, 1147.6, and $1097.4 \mathrm{mg} / \mathrm{kg} \mathrm{dw}$, which are higher than the values observed in this study [32].

$\mathrm{Mg}$ and $\mathrm{Zn}$ concentrations in different Boletus were in the ranges of 386-1239 and 45-223 mg/kg dw for caps and 279935 and $33-131 \mathrm{mg} / \mathrm{kg} \mathrm{dw}$ for stalks, respectively, which coincide with the literature reports [5]. $\mathrm{Cu}$ and $\mathrm{Mn}$ contents in Boletus badius, Boletus luridus, and Boletus edulis were found to be lower than the results in our study, that is, 33-78 and $17-67 \mathrm{mg} / \mathrm{kg} \mathrm{dw}$ for caps and $16-39$ and $26-85 \mathrm{mg} / \mathrm{kg} \mathrm{dw}$ for stalks, respectively $[5,33,34]$. Other species such as Macrolepiota procera and Lepista nuda contained higher content of $\mathrm{Cu}(236.5 \mathrm{mg} / \mathrm{kg} \mathrm{dw})$ and $\mathrm{Mn}(480 \mathrm{mg} / \mathrm{kg} \mathrm{dw})[6,31]$. The range of $\mathrm{Na}$ contents in caps was $105-601 \mathrm{mg} / \mathrm{kg} \mathrm{dw}$ and $90-$ $500 \mathrm{mg} / \mathrm{kg}$ dw in stalks, which are lower than values in species such as Boletus subtomentosus (77-1200 mg/kg dw), Pleurotus ostreatus (220-1400 mg/kg dw), and Agaricus bisporus (16000-25000 mg/kg dw) [26, 35, 36].

Uneven distribution of elements between caps and stalks is shown in Table 2. The caps of Boletus contained higher contents of $\mathrm{K}, \mathrm{P}, \mathrm{Cu}, \mathrm{Mg}$, and $\mathrm{Zn}$ and lower contents of $\mathrm{Mn}$ when compared to stalks. Reports also suggested similar results for these elements in Boletus edulis, Boletus subtomentosus, and Boletus scaber $[26,37,38]$. However, the contents of $\mathrm{Ca}, \mathrm{Fe}$, and $\mathrm{Na}$ between caps and stalks have no certain regularity
(Table 2). Contents of $\mathrm{Cu}, \mathrm{P}$, and $\mathrm{Zn}$ in caps are approximately twice or even thrice higher than in stalks, and similar findings were obtained in the review of Falandysz and Borovička [5]. As can be seen from Table 2, both caps and stalks can be considered as abundant in $\mathrm{P}, \mathrm{K}, \mathrm{Fe}, \mathrm{Mg}, \mathrm{Zn}$, and $\mathrm{Ca}$, and Boletus could be considered potential dietary sources of these essential elements to humans.

According to the EU Scientific Committee, $60 \mathrm{~kg}$ of body weight was used for intake calculations. For intake calculations, usually a $300 \mathrm{~g}$ portion of fresh mushrooms per meal is assumed, which contains $30 \mathrm{~g}$ of dry matter [39]. The elements intakes by a normal $(60 \mathrm{~kg})$ consumer in $\mathrm{mg}$ per serving for all studied fruiting bodies are presented in Table 3.

3.2. Bioconcentration Factor (BCF). Bioconcentration factor (BCF) values in caps and stalks of Boletus are summarized in Table 4. Among the elements determined, $\mathrm{P}$ and $\mathrm{K}$ exhibit BCF $>1$, except for BCF for stalk of Boletus edulis (Table 4), while $\mathrm{Ca}, \mathrm{Fe}, \mathrm{Mg}, \mathrm{Mn}$, and $\mathrm{Na}$ are bioexcluded $(\mathrm{BCF}<1)$ by the Boletus species studied. Although a certain element in the soil is abundant and could accumulate to relatively high contents in the mushroom, BCF below 1 may be obtained, which was reported for $\mathrm{Ca}, \mathrm{Fe}, \mathrm{Mg}, \mathrm{Mn}$, and $\mathrm{Na}$ in a recent study [8].

Wild mushrooms such as Pholiota nameko, Tricholoma quercicol, and Ramaria flava collected from Sichuan province (China) showed lower BCF values for potassium, that is, 0.84 , 0.48 , and 0.5 , respectively [40]. Higher BCF values for $K$, $\mathrm{Na}, \mathrm{Zn}, \mathrm{Cu}, \mathrm{P}$, and $\mathrm{Mg}$ were found in Boletus subtomentosus, namely, 4400, 340, 110, 77, 40, and 21 for caps and 3900, $310,67,27,18$, and 11 for stalks, respectively [26]. Boletus edulis collected from Poland also showed higher levels of BCF values for $\mathrm{Cu}$ and $\mathrm{Zn}$, that is, 3.6-31 for caps and 1.7-16 for 
TABLE 4: Bioconcentration factor (BCF) values of caps and stipes of Boletus.

\begin{tabular}{|c|c|c|c|c|c|c|c|c|c|c|}
\hline Species & & $\mathrm{Ca}$ & $\mathrm{Cu}$ & $\mathrm{Fe}$ & $\mathrm{K}$ & $\mathrm{Mg}$ & $\mathrm{Mn}$ & $\mathrm{Na}$ & $\mathrm{P}$ & $\mathrm{Zn}$ \\
\hline \multirow{2}{*}{ Boletus speciosus } & aps & $0.38 \pm 0.1$ & $1.89 \pm 0.24$ & $5 \pm 0.01$ & $2.85 \pm 0.57$ & $0.80 \pm 0.03$ & $0.15 \pm 0.02$ & $0.15 \pm 0.04$ & $8.55 \pm 1.27$ & $2.35 \pm 0.78$ \\
\hline & & & 29 & .04 & $1.93 \pm$ & .18 & & & & $0.89 \pm$ \\
\hline \multirow{2}{*}{ Boletus griseu } & & & & & 3. & 07 & & & 88 & 12 \\
\hline & & $0.48 \pm 0.05$ & $0.62 \pm 0.06$ & $0.04 \pm$ & 2.8 & 0.3 & & & & \\
\hline \multirow{2}{*}{ Boletus luridus } & & 04 & 37 & $0.06 \pm c$ & 1.6 & 11 & & & & 1. \\
\hline & & $0.16 \pm 0.08$ & $0.37 \pm 0.02$ & $0.04 \pm 0.01$ & $1.14 \pm 0.52$ & $0.13 \pm$ & & & & \\
\hline \multirow{2}{*}{ Boletus umbriniporus } & & $0.2 \pm$ & $1.7 \pm$ & $0.04 \pm$ & $2.08 \pm$ & $0.44 \pm$ & & $0.2 \pm$ & & \\
\hline & Stipes & 0.13 & & & & & & $0.22 \pm 0.16$ & & \\
\hline \multirow{2}{*}{ Boletus tomentipes } & & & & & & & & & & \\
\hline & & & & $0.02 \pm($ & $1.87 \pm$ & $0.28 \pm$ & & $0.16 \pm$ & $3.63 \pm$ & \\
\hline \multirow{2}{*}{ Boletus edulis } & & $0.2 \pm c$ & $0.3 \pm$ & & & & & & $4.42 \pm$ & \\
\hline & Stipes & $0.2 \pm 0$ & $0.21 \pm 0.03$ & $0.08 \pm 0.07$ & $0.57 \pm 0.01$ & $0.08 \pm 0.02$ & $0.07 \pm 0.03$ & $0.06 \pm 0.02$ & $1.62 \pm 0.43$ & $0.3 \pm$ \\
\hline \multirow{2}{*}{ Boletus pallidus } & & $0.1 \pm 0.06$ & $0.3 \pm 0.14$ & $0.02 \pm 0.01$ & $5.2 \pm 1.46$ & $0.71 \pm 0.15$ & $0.03 \pm 0.02$ & $0.5 \pm 0.27$ & $7.98 \pm 2.19$ & $0.11 \pm 0.04$ \\
\hline & Stipes & $0.1 \pm 0.04$ & $0.15 \pm 0.02$ & $0.02 \pm 0.01$ & $4.24 \pm 0.58$ & $0.54 \pm 0.09$ & $0.04 \pm 0.03$ & $0.39 \pm 0.14$ & $4.23 \pm 0.88$ & $0.1 \pm 0.02$ \\
\hline \multirow{2}{*}{ Boletus brunneissimus } & & $0.36 \pm 0.07$ & $0.66 \pm 0.28$ & $0.02 \pm 0.01$ & $1.74 \pm 0.42$ & $0.58 \pm 0.01$ & $0.04 \pm 0.02$ & $0.53 \pm 0.23$ & $2.46 \pm 0.67$ & $1.15 \pm$ \\
\hline & Stipes & $0.08 \pm 0.04$ & $0.32 \pm 0.08$ & $0.02 \pm 0.01$ & $1.53 \pm 1.2$ & $0.39 \pm 0.14$ & $0.05 \pm 0.01$ & & $1.47 \pm 0.28$ & $0.61 \pm 0.03$ \\
\hline \multirow{2}{*}{ Boletus rubellus } & Caps & $0.09 \pm 0.02$ & $0.35 \pm 0.16$ & $0.02 \pm 0.01$ & $2.05 \pm 1.07$ & $0.43 \pm 0.29$ & $0.06 \pm 0.02$ & $0.25 \pm 0.04$ & $2.71 \pm 0.78$ & $0.89 \pm 0.06$ \\
\hline & Stipes & $0.19 \pm 0.07$ & $0.22 \pm 0.1$ & $0.06 \pm 0.01$ & $1.89 \pm 0.76$ & $0.35 \pm 0.2$ & $0.1 \pm 0.06$ & $0.41 \pm 0.27$ & $2.23 \pm 0.55$ & $0.52 \pm 0.12$ \\
\hline \multirow{2}{*}{ Boletus aereus } & & $0.2 \pm 0.09$ & $1.02 \pm 0.34$ & $0.02 \pm 0.01$ & $2.0 \pm 1.07$ & $0.49 \pm 0.23$ & $0.07 \pm 0.02$ & $0.23 \pm 0.01$ & $7.87 \pm 2.09$ & $2.14 \pm 0.24$ \\
\hline & Stipes & $0.2 \pm 0.04$ & $0.62 \pm 0.01$ & $0.07 \pm 0.03$ & $1.39 \pm 0.56$ & $0.36 \pm 0.21$ & $0.2 \pm 0.17$ & $0.12 \pm 0.04$ & $3.59 \pm 1.22$ & $0.97 \pm 0.43$ \\
\hline
\end{tabular}

TABLE 5: Correlation matrix that gives the relationship between element concentrations of caps and underlying soil.

\begin{tabular}{|c|c|c|c|c|c|c|c|c|c|}
\hline \multirow{2}{*}{ Elements in soils } & \multicolumn{9}{|c|}{ Elements in mushrooms } \\
\hline & $\mathrm{Ca}$ & $\mathrm{Cu}$ & $\mathrm{Fe}$ & $\mathrm{K}$ & $\mathrm{Mg}$ & $\mathrm{Mn}$ & $\mathrm{Na}$ & $\mathrm{P}$ & $\mathrm{Zn}$ \\
\hline $\mathrm{Ca}$ & 0.406 & 0.262 & $0.681^{*}$ & 0.299 & 0.322 & 0.57 & -0.031 & 0.445 & 0.065 \\
\hline $\mathrm{Cu}$ & 0.021 & 0.556 & 0.487 & 0.475 & 0.58 & 0.1 & 0.289 & $0.775^{* *}$ & -0.392 \\
\hline $\mathrm{Fe}$ & 0.01 & 0.492 & 0.382 & 0.509 & 0.54 & 0.061 & 0.322 & $0.728^{*}$ & -0.355 \\
\hline K & 0.327 & -0.477 & -0.162 & -0.362 & $-0.644^{*}$ & 0.159 & -0.233 & -0.305 & 0.067 \\
\hline $\mathrm{Mg}$ & 0.173 & 0.242 & 0.372 & -0.217 & -0.176 & 0.345 & -0.318 & 0.257 & -0.262 \\
\hline $\mathrm{Mn}$ & 0.52 & 0.253 & 0.563 & 0.403 & 0.328 & 0.431 & 0.241 & $0.667^{*}$ & -0.336 \\
\hline $\mathrm{Na}$ & -0.131 & 0.214 & 0.09 & -0.217 & -0.232 & 0.22 & 0.174 & 0.046 & -0.321 \\
\hline $\mathrm{P}$ & 0.582 & -0.5 & 0.292 & 0.186 & -0.092 & 0.294 & 0.111 & 0.016 & 0.276 \\
\hline $\mathrm{Zn}$ & 0.137 & 0.423 & 0.483 & $0.673^{*}$ & $0.675^{*}$ & 0.128 & 0.456 & $0.760^{*}$ & -0.295 \\
\hline
\end{tabular}

${ }^{*}$ Correlation is significant at the 0.05 level (2-tailed).

${ }^{* *}$ Correlation is significant at the 0.01 level (2-tailed).

stipes [41]. In the study by Ma et al., BCF values of $\mathrm{Zn}$ and $\mathrm{Cu}$ were less than 0.01 in five kinds of wild edible Boletus from China [42]. In early studies, the blockage of $\mathrm{Ca}, \mathrm{Fe}$, and $\mathrm{Mn}(\mathrm{BCF}<1)$ was reported in fruiting body of Macrolepiota procera, Leccinum griseum, and Tricholoma quercicol [27, 29, 40,43 , which agrees with our results.

3.3. Correlation Analysis. Matrices of correlation coefficients among elements concentrations of the fruiting body (caps and stalks) and underlying soils are presented in Tables 5 and 6. $\mathrm{Cu}(r=0.556)$ and $\mathrm{Mn}(r=0.431)$ had significant correlations in caps, and high correlation were seen between $\mathrm{Ca}(r=$ $0.727), \mathrm{Cu}(r=0.6)$, and $\mathrm{Fe}(r=0.569)$ in stalks. Similar results were obtained for $\mathrm{Cu}(r=0.478), \mathrm{Mn}(r=0.389)$, and $\mathrm{Fe}$ $(r=0.417)$ in Verpa conica, Tricholoma terreum, and Boletus badius, respectively [44]. Meanwhile, significant correlations were also found between $\mathrm{Ca}-\mathrm{Fe}(r=0.681), \mathrm{Cu}-\mathrm{P}(r=0.775)$, Fe-P $(r=0.728), \mathrm{Mn}-\mathrm{P}(r=0.667), \mathrm{Zn}-\mathrm{K}(r=0.673), \mathrm{Zn}-\mathrm{Mg}$ $(r=0.675)$, and $\mathrm{Zn}-\mathrm{P}(r=0.76)$ for caps. For stalks, significant correlations were found between $\mathrm{Cu}-\mathrm{Mg}(r=0.721), \mathrm{Cu}-\mathrm{P}(r=$ $0.659), \mathrm{Fe}-\mathrm{Mg}(r=0.719), \mathrm{Fe}-\mathrm{P}(r=0.693), \mathrm{Zn}-\mathrm{Mg}(r=0.824)$, $\mathrm{Zn}-\mathrm{P}(r=0.684)$, and $\mathrm{Zn}-\mathrm{P}(r=0.818)$.

\section{Conclusion}

The present study gives an overview for the levels of elements accumulation, determined in caps and stalks of ten species of Boletus from Yunnan province, southwest of China. From the nutritional point of view, these Boletus could be considered as a potential dietary source of essential elements such as 
TABLE 6: Correlation matrix that gives the relationship between element concentrations of stipes and underlying soil.

\begin{tabular}{|c|c|c|c|c|c|c|c|c|c|}
\hline \multirow{2}{*}{ Elements in soils } & \multicolumn{9}{|c|}{ Elements in mushrooms } \\
\hline & $\mathrm{Ca}$ & $\mathrm{Cu}$ & $\mathrm{Fe}$ & $\mathrm{K}$ & $\mathrm{Mg}$ & Mn & $\mathrm{Na}$ & $\mathrm{P}$ & $\mathrm{Zn}$ \\
\hline $\mathrm{Ca}$ & $0.727^{*}$ & 0.133 & 0.423 & 0.307 & 0.469 & 0.374 & 0.234 & 0.62 & 0.204 \\
\hline $\mathrm{Cu}$ & 0.482 & 0.6 & 0.6 & 0.33 & $0.721^{*}$ & 0.112 & 0.472 & $0.659^{*}$ & -0.156 \\
\hline $\mathrm{Fe}$ & 0.452 & 0.601 & 0.569 & 0.405 & $0.719^{*}$ & 0.113 & 0.452 & $0.693^{*}$ & -0.057 \\
\hline $\mathrm{K}$ & 0.094 & -0.173 & 0.445 & -0.384 & -0.544 & 0.537 & -0.422 & -0.307 & 0.054 \\
\hline $\mathrm{Mg}$ & 0.336 & 0.091 & $0.718^{*}$ & -0.439 & -0.145 & 0.628 & -0.316 & -0.103 & -0.318 \\
\hline $\mathrm{Mn}$ & 0.495 & 0.181 & 0.497 & 0.224 & 0.435 & 0.334 & 0.233 & 0.474 & -0.197 \\
\hline $\mathrm{Na}$ & -0.164 & 0.281 & 0.175 & -0.464 & -0.253 & 0.47 & 0.089 & -0.442 & -0.571 \\
\hline $\mathrm{P}$ & 0.522 & -0.056 & 0.171 & 0.295 & 0.027 & 0.05 & 0.359 & 0.378 & 0.338 \\
\hline $\mathrm{Zn}$ & 0.466 & 0.505 & 0.26 & 0.626 & $0.824^{* *}$ & -0.126 & $0.684^{*}$ & $0.818^{* *}$ & -0.012 \\
\hline
\end{tabular}

${ }^{*}$ Correlation is significant at the 0.05 level (2-tailed).

${ }^{* *}$ Correlation is significant at the 0.01 level (2-tailed).

$\mathrm{P}, \mathrm{K}, \mathrm{Mg}, \mathrm{Cu}, \mathrm{Zn}, \mathrm{Mn}$, and Fe. Elements $\mathrm{K}, \mathrm{P}, \mathrm{Cu}, \mathrm{Mg}$, and $\mathrm{Zn}$ are preferably accumulated in the cap of Boletus, while $\mathrm{Mn}$ is preferably accumulated in stalk. Depending on the environmental conditions and mushroom species, the values of BCF varied highly depending on chemical element and were $>1$ for $\mathrm{P}$ and $\mathrm{K}$, while they were $<1$ for $\mathrm{Ca}, \mathrm{Fe}, \mathrm{Mg}, \mathrm{Mn}$, and $\mathrm{Na}$. The correlation analysis showed that $\mathrm{Cu}, \mathrm{Mn}, \mathrm{Ca}$, and Fe contents were highly correlated in the mushrooms as compared to the corresponding soils. Significant correlations were also obtained between $\mathrm{Cu}-\mathrm{P}(r=0.775)$, Fe-P $(r=0.728)$, and $\mathrm{Zn}-\mathrm{P}(r=0.76)$ for caps and $\mathrm{Cu}-\mathrm{Mg}(r=0.721), \mathrm{Fe}-\mathrm{Mg}(r$ $=0.719), \mathrm{Zn}-\mathrm{Mg}(r=0.824)$, and $\mathrm{Zn}-\mathrm{P}(r=0.818)$ for stalks.

\section{Conflict of Interests}

The authors declare that there is no conflict of interests regarding the publication of this paper.

\section{Acknowledgments}

This study has been supported by the National Natural Science Foundation of China (31460538, 31260496, and 31160409), the Special Project on the Countryside Comprehensive Reform (2014NG007-18), and the Science Foundation of the Yunnan Province Department of Education (2013Z074).

\section{References}

[1] X.-M. Wang, J. Zhang, L.-H. Wu et al., "A mini-review of chemical composition and nutritional value of edible wildgrown mushroom from China," Food Chemistry, vol. 151, pp. 279-285, 2014.

[2] X. Zeng, J. Suwandi, J. Fuller, A. Doronila, and K. Ng, "Antioxidant capacity and mineral contents of edible wild Australian mushrooms," Food Science and Technology International, vol. 18, no. 4, pp. 367-379, 2012.

[3] E. Vamanu and S. Nita, "Antioxidant capacity and the correlation with major phenolic compounds, anthocyanin, and tocopherol content in various extracts from the wild edible Boletus edulis mushroom," BioMed Research International, vol. 2013, Article ID 313905, 11 pages, 2013.
[4] P. Kalač, "A review of chemical composition and nutritional value of wild-growing and cultivated mushrooms," Journal of the Science of Food and Agriculture, vol. 93, no. 2, pp. 209-218, 2013.

[5] J. Falandysz and J. Borovička, "Macro and trace mineral constituents and radionuclides in mushrooms-health benefits and risks," Applied Microbiology and Biotechnology, vol. 97, no. 2, pp. 477-501, 2013.

[6] N. Mazurkiewicz and J. Podlasińska, "Bioaccumulation of trace elements in wild-growing edible mushrooms from Lubuskie voivodeship, Poland," Chemistry and Ecology, vol. 30, no. 2, pp. 110-117, 2014.

[7] P. Kalač, "Trace element contents in European species of wild growing edible mushrooms: a review for the period 2000-2009," Food Chemistry, vol. 122, no. 1, pp. 2-15, 2010.

[8] A. Frankowska, J. Ziołkowska, L. Bielawski, and J. Falandysz, "Profile and bioconcentration of minerals by King Bolete (Boletus edulis) from the Płocka Dale in Poland," Food Additives and Contaminants: Part B Surveillance, vol. 3, no. 1, pp. 1-6, 2010.

[9] G. F. Yu and Y. S. Chen, "Soil distribution in Yunnan," Journal of Yunnan University, vol. 20, no. 1, pp. 55-58, 1998.

[10] Z. H. Zeng and X. P. Zeng, "The relationship between cancer death rate and chemical elements in soil of Yunnan province," Yunnan Geology, vol. 22, no. 4, pp. 395-402, 2003.

[11] S.-R. Wu, X.-L. Luo, B. Liu, and M.-Y. Gui, "Analyse and advise to research and development of wild edible fungi," Food Science and Technology, vol. 35, pp. 100-103, 2010.

[12] Q. Zhang and X. F. Yang, "Export status, problems and countermeasures of wild mushrooms in Yunnan province," Technology and Market, vol. 20, no. 5, pp. 316-318, 2013.

[13] G. Jaworska and E. Bernaś, "The effect of preliminary processing and period of storage on the quality of frozen Boletus edulis (Bull: Fr.) mushrooms," Food Chemistry, vol. 113, no. 4, pp. 936943, 2009.

[14] L. M. Tai, C. Y. Zhao, X. Guo, M. Ma, and B. Liu, "Prospects of exploitation and utilization on several kinds of high economic value of wild edible and medicinal fungi resource in Yunnan," Edible Fungi of China, vol. 32, pp. 4-6, 2013.

[15] S. A. Heleno, L. Barros, M. J. Sousa, A. Martins, C. SantosBuelga, and I. C. F. R. Ferreira, "Targeted metabolites analysis in wild Boletus species," LWT_Food Science and Technology, vol. 44, no. 6, pp. 1343-1348, 2011. 
[16] L. Cocchi, L. Vescovi, L. E. Petrini, and O. Petrini, "Heavy metals in edible mushrooms in Italy," Food Chemistry, vol. 98, no. 2, pp. 277-284, 2006.

[17] D. Zhang, T. Gao, P. Ma, Y. Luo, and P. Su, "Bioaccumulation of heavy metal in wild growing mushrooms from Liangshan Yi Nationality Autonomous Prefecture, China," Wuhan University Journal of Natural Sciences, vol. 13, no. 3, pp. 267-272, 2008.

[18] J. Falandysz, H. Bona, and D. Danisiewicz, "Silver content of wild-grown mushrooms from Northern Poland," Zeitschrift für Lebensmittel-Untersuchung und Forschung, vol. 199, no. 3, pp. 222-224, 1994.

[19] J. Borovička, Z. Řanda, and E. Jelínek, "Antimony content of macrofungi from clean and polluted areas," Chemosphere, vol. 64, no. 11, pp. 1837-1844, 2006.

[20] H. G. Liu, Y. Z. Wang, T. Li et al., "ICP-AES determination of 11 metals in 16 species of wild mushrooms from Yunnan province," Chinese Journal of Spectroscopy Laboratory, vol. 29, pp. 71-74, 2012.

[21] M. Aloupi, G. Koutrotsios, M. Koulousaris, and N. Kalogeropoulos, "Trace metal contents in wild edible mushrooms growing on serpentine and volcanic soils on the island of Lesvos, Greece," Ecotoxicology and Environmental Safety, vol. 78, pp. 184-194, 2012.

[22] G. M. Gadd, "Geomycology: biogeochemical transformations of rocks, minerals, metals and radionuclides by fungi, bioweathering and bioremediation," Mycological Research, vol. 111, no. 1, pp. 3-49, 2007.

[23] L. X. Zhou and J. Z. Yin, "Yunnan wild edible Boletus nutrition analysis and evaluation," Edible Fungi, vol. 4, pp. 61-62, 2008.

[24] T. Li, Y. Wang, J. Zhang, Y. Zhao, and H. Liu, "Trace element content of Boletus tomentipes mushroom collected from Yunnan, China," Food Chemistry, vol. 127, no. 4, pp. 1828-1830, 2011.

[25] H. G. Liu, J. Zhang, T. Li, Y. Shi, and Y. Wang, "Mineral element levels in wild edible mushrooms from Yunnan, China," Biological Trace Element Research, vol. 147, no. 1-3, pp. 341-345, 2012.

[26] G. Jarzyńska, A. Chojnacka, A. Dryzalowska, I. C. Nnorom, and J. Falandysz, "Concentrations and bioconcentration bactors of minerals in Yellow-Cracking Bolete (Xerocomus Subtomentosus) mushroom collected in Notec forest, Poland," Journal of Food Science, vol. 77, no. 9, pp. H202-H206, 2012.

[27] E. Kułdo, G. Jarzyńska, M. Gucia, and J. Falandysz, "Mineral constituents of edible parasol mushroom Macrolepiota procera (Scop. ex Fr.) Sing and soils beneath its fruiting bodies collected from a rural forest area," Chemical Papers, vol. 68, no. 4, pp. 484492, 2014.

[28] H. Gençcelep, Y. Uzun, Y. Tunçtürk, and K. Demirel, "Determination of mineral contents of wild-grown edible mushrooms," Food Chemistry, vol. 113, no. 4, pp. 1033-1036, 2009.

[29] G. Jarzyńska and J. Falandysz, "Metallic elements profile of Hazel (Hard) Bolete (Leccinum griseum) mushroom and associated upper soil horizon," African Journal of Biotechnology, vol. 11, no. 20, pp. 4588-4594, 2012.

[30] E. Sesli, M. Tuzen, and M. Soylak, "Evaluation of trace metal contents of some wild edible mushrooms from Black sea region, Turkey," Journal of Hazardous Materials, vol. 160, no. 2-3, pp. 462-467, 2008.

[31] M. Yamaç, D. Yildiz, C. Sarikürkcü, M. Çelikkollu, and M. H. Solak, "Heavy metals in some edible mushrooms from the Central Anatolia, Turkey," Food Chemistry, vol. 103, no. 2, pp. 263-267, 2007.
[32] P. Zhu, Y. H. Guo, X. W. Ding et al., "Analysis components of 4 kinds of fresh Boletus sp," Edible Fungi of China, vol. 125, no. 4, pp. 44-46, 2006.

[33] D. Mendil, Ö. D. Uluözlü, E. Hasdemir, and A. Çaǧlar, "Determination of trace elements on some wild edible mushroom samples from Kastamonu, Turkey," Food Chemistry, vol. 88, no. 2, pp. 281-285, 2004.

[34] D. Zhang, A. Frankowska, G. Jarzyńska et al., "Metals of king bolete (Boletus edulis) bull.: Fr. collected at the same site over two years," African Journal of Agricultural Research, vol. 5, no. 22, pp. 3050-3055, 2010.

[35] J. Vetter, C. Hajdú, J. Györfi, and P. Maszlavér, "Mineral composition of the cultivated mushrooms Agaricus bisporus, Pleurotus ostreatus and Lentinula edodes," Acta Alimentaria, vol. 34, no. 4, pp. 441-451, 2005.

[36] J. Vetter, "Chemical composition of fresh and conserved Agaricus bisporus mushroom," European Food Research and Technology, vol. 217, no. 1, pp. 10-12, 2003.

[37] J. Falandysz, T. Kunito, R. Kubota et al., "Multivariate characterization of elements accumulated in King Bolete Boletus edulis mushroom at lowland and high mountain regions," Journal of Environmental Science and Health Part A, vol. 43, no. 14, pp. 1692-1699, 2008.

[38] D. Zhang, Y. Zhang, E. Morawska et al., "Trace elements in Leccinum scabrum mushrooms and topsoils from Kłodzka Dale in Sudety Mountains, Poland," Journal of Mountain Science, vol. 10 , no. 4, pp. 621-627, 2013.

[39] X.-H. Chen, H.-B. Zhou, and G.-Z. Qiu, "Analysis of several heavy metals in wild edible mushrooms from regions of China," Bulletin of Environmental Contamination and Toxicology, vol. 83, no. 2, pp. 280-285, 2009.

[40] Z. P. Wang, D. Y. Fan, Q. H. Huang, Y. Z. Zhao, and S. Q. Ruan, "Study on the content of mineral element in several kinds of wild edible fungi and the correlation with the soil," Journal of Anhui Agriculture, vol. 39, no. 27, pp. 16527-16529, 2011.

[41] F. Jerzy, A. Frankowska, G. Jarzyńska, D. Anna, A. K. Kojta, and D. Zhang, "Survey on composition and bioconcentration potential of 12 metallic elements in king bolete (boletus edulis) mushroom that emerged at 11 spatially distant sites," Journal of Environmental Science and Health Part B: Pesticides, Food Contaminants, and Agricultural Wastes, vol. 46, no. 3, pp. 231246, 2011

[42] P. Ma, D. Zhang, L. B. Yang et al., "Bioaccumulation of heavy metal in wild edible Boletus fruiting body," Environmental Science \& Technology, vol. 35, pp. 5-8, 2012.

[43] K. Chudzyński and J. Falandysz, "Multivariate analysis of elements content of Larch Bolete (Suillus grevillei) mushroom," Chemosphere, vol. 73, no. 8, pp. 1230-1239, 2008.

[44] Ö. Isildak, I. Turkekul, M. Elmastas, and H. Y. Aboul-Enein, "Bioaccumulation of heavy metals in some wild-grown edible mushrooms," Analytical Letters, vol. 40, no. 6, pp. 1099-1116, 2007. 

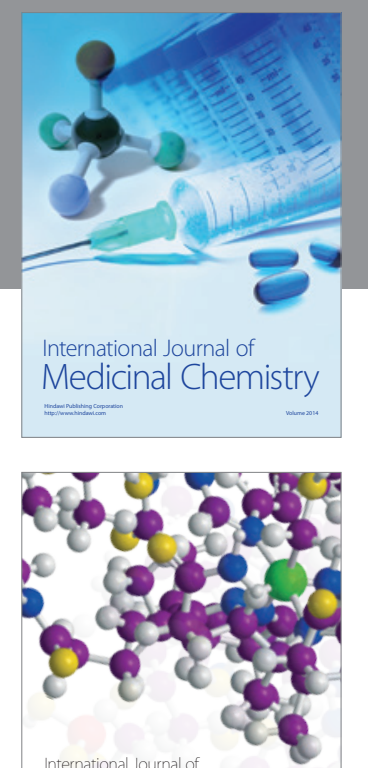

\section{Carbohydrate} Chemistry

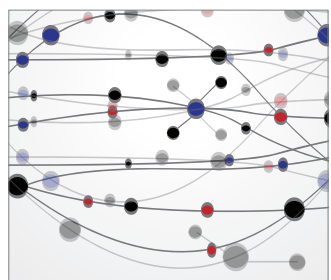

The Scientific World Journal
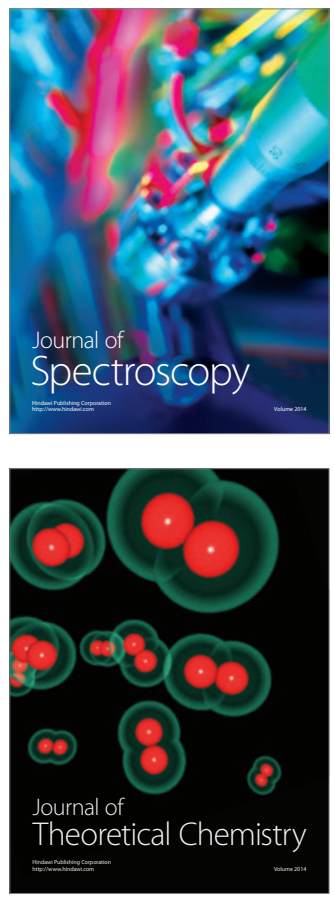
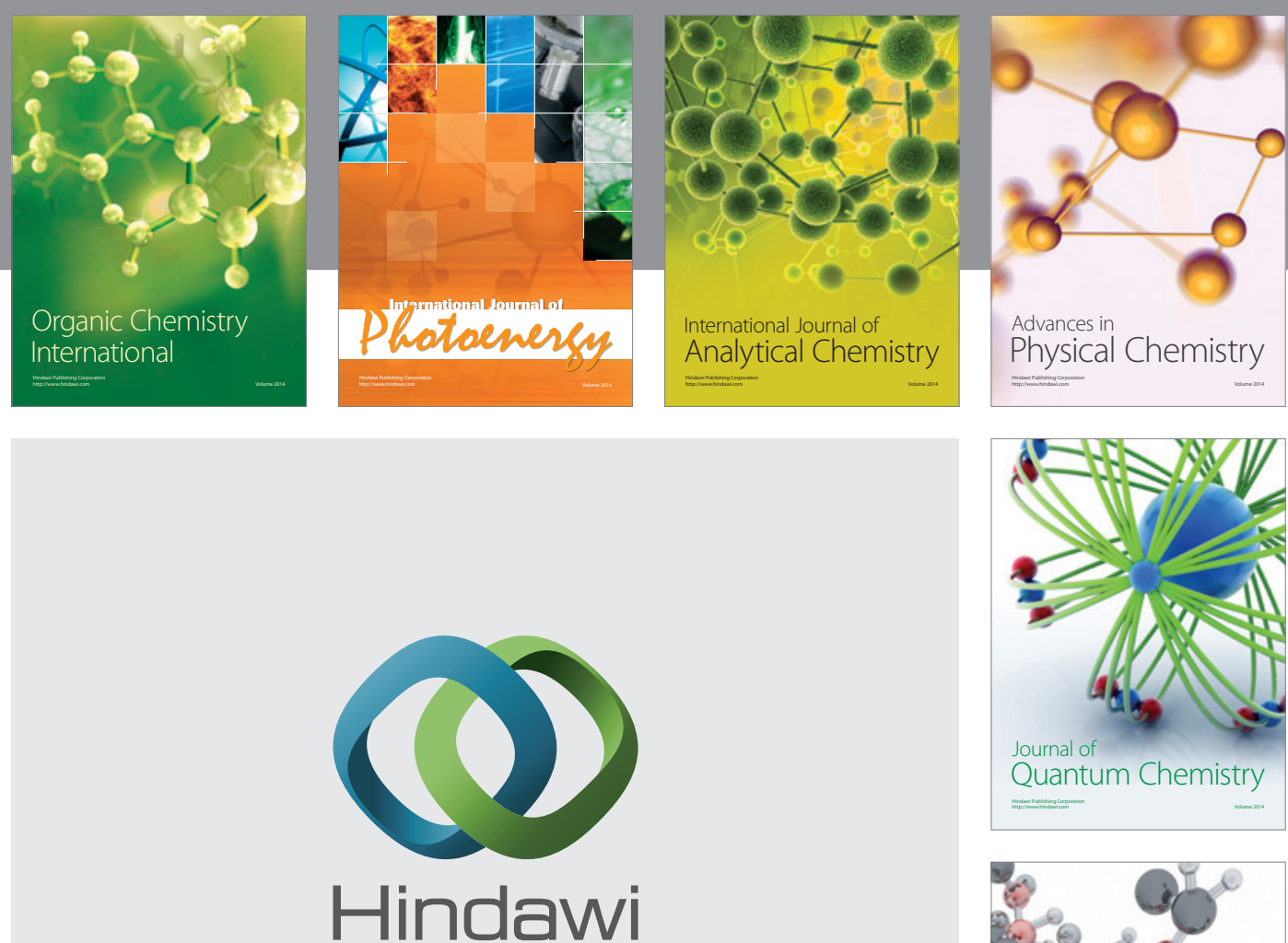

Submit your manuscripts at

http://www.hindawi.com

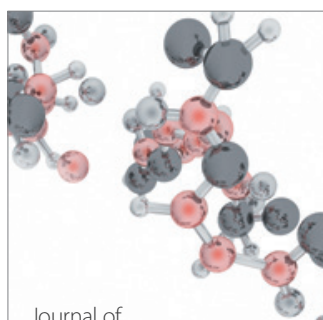

Analytical Methods

in Chemistry

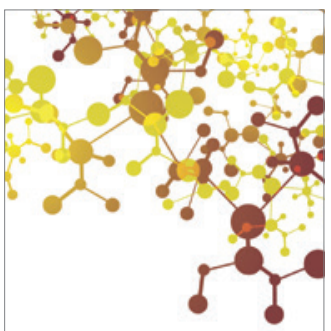

Journal of

Applied Chemistry

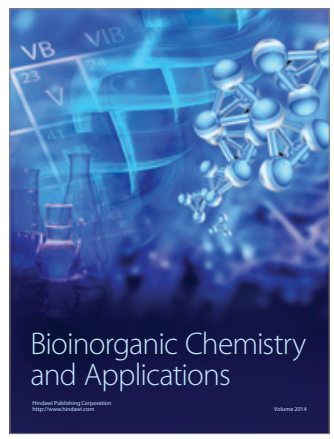

Inorganic Chemistry
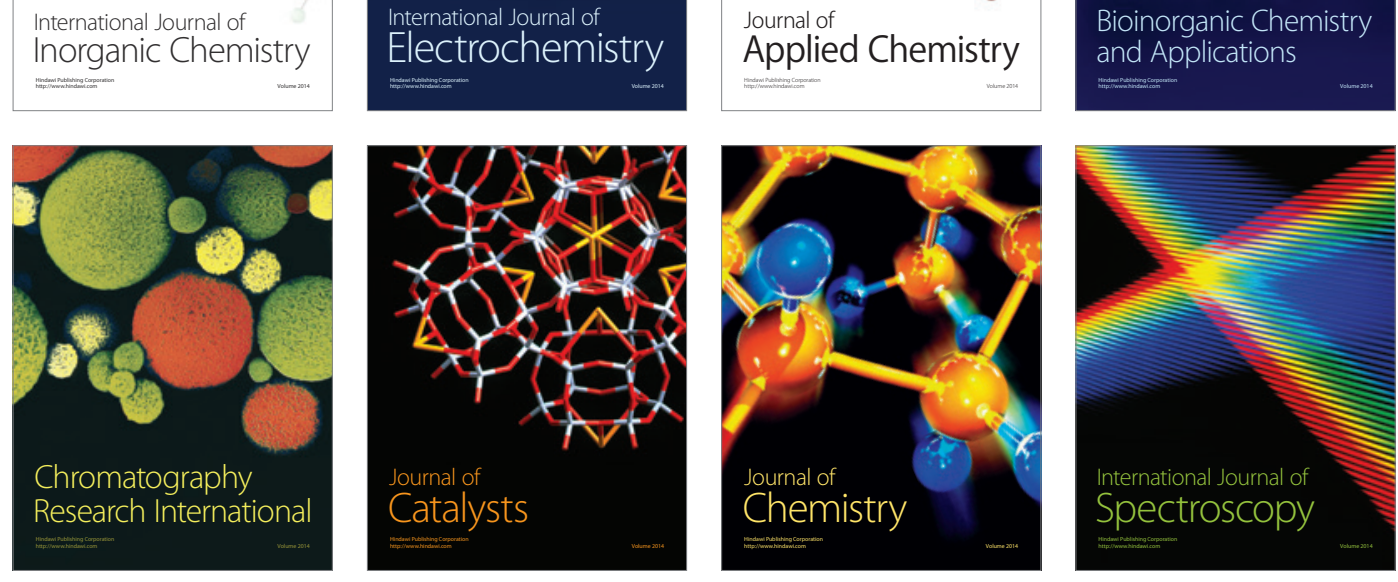